\title{
Research on Arts and Humanities: A Selected Survey and Works Presented at ATINER's Annual Humanities and Arts Conferences
}

\author{
By David P. Wick*, Aleksandra Tryniecka ${ }^{ \pm}$Olga Gkounta
}

\begin{abstract}
This paper presents a survey of twenty-six research presentations at the $9^{\text {th }}$ Annual International Conference which took place in Athens, 3-4 January 2022. Participants were coming from thirteen different countries (Brazil, Canada, Cyprus, Hungary, India, Italy, Republic of Korea, Romania, Senegal, Serbia, South Africa, Spain, and USA). The aim of this survey is to summarize the main research findings. These presentations covered a wide range of themes in the field of Humanities and Arts. In addition, this survey provides an overview of all the previous annual conferences of Humanities and Arts which always take place in Athens every year in the first week of January.
\end{abstract}

\section{Introduction}

The 2022 Humanities and Arts Conference is the ninth that was organized by the Athens Institute for Education and Research (ATINER), a world association of academics and researchers based in Athens. Our institution had been soliciting the best and most engaging papers we could invite to Athens on the arts and humanities almost since the millennium began, but starting in 2014 we were proud to give these studies - so easily forgotten in our technical age - their own research division, their own "flagship" conference, and - before long - their own Athenian-published journal.

The conference serves the mission of the association which is to provide the "fertile ground" to academics and researchers from all over the world to convene in Athens in small groups much as they did in the ancient Athenian symposiums, to exchange ideas, share their research and to discuss the future frontiers of their disciplines, and to engage with professionals from other fields as they do. The broad spectrum of subjects covered by this specific conference makes it unique. In these ways we help participants broaden their horizons not only because of the wide geographical coverage of our visiting presenters, but because academics have the chance to listen in an intimate space to such a variety of themes as they come together from so many vectors within the Humanities and Arts field. Most importantly it creates the ground for research collaborations among the participants who start with perspectives from higher education institutes in all

"Director, Arts, Humanities and Education Division, ATINER \& Retired Professor, Gordon College, USA.

ŁLecturer, Maria Curie-Skłodowska University in Lublin, Poland.

'Researcher, ATINER, Greece. 
corners of the world: Africa, America, Asia, Europe; academics need this in an era as globalizing as our own has become.

So, as we said, we have purposed these small academic conferences to bring academics from a myriad of countries together - to talk about current, future research, to generate collaborative interest with samples of their work. Since 2014, 236 presentations 48 different countries have launched in our small conference rooms (Argentina, Australia, Austria, Brazil, Bulgaria, Canada, China, Croatia, Cyprus, Czech Republic, Egypt, Finland, France, Georgia, Germany, Hong Kong, India, Iran, Israel, Italy, Japan, Kenya, Kuwait, Malaysia, New Zealand, Nigeria, Oman, Philippines, Poland, Portugal, Qatar, Republic of Armenia, Republic of Korea, Romania, Russia, Senegal, Serbia, Singapore, South Africa, Spain, Sri Lanka, Taiwan, Tunisia, Turkey, UAE, Uganda, UK, and USA), as it can be seen in Table 1.

Table 1. Publication of Books of Abtracts of Proceedings, 2014-2022

\begin{tabular}{|l|c|c|c|}
\hline Year & Papers & Countries & Reference \\
\hline 2022 & 26 & 13 & Wick et al. (2022) \\
\hline 2021 & 17 & 10 & Papanikos (2021) \\
\hline 2020 & 25 & 10 & Papanikos (2020) \\
\hline 2019 & 23 & 16 & Papanikos (2019) \\
\hline 2018 & 25 & 11 & Papanikos (2018) \\
\hline 2017 & 24 & 12 & Papanikos (2017) \\
\hline 2016 & 30 & 14 & Papanikos (2016) \\
\hline 2015 & 37 & 23 & Papanikos (2015) \\
\hline 2014 & 29 & 16 & Papanikos (2014) \\
\hline
\end{tabular}

\section{Previous Journal Publications of the Humanities and Arts Papers based on Conference Presentations}

It is ATINER's policy not to publish books of paper proceedings presented at its various conferences. Presenters have the option to see their work printed in one of the sixteen peer-reviewed e-journals published by ATINER since 2014. From all the previous (eight) conferences of Humanities and Arts twenty-five papers of various thematics have been published in journal publications.

Diving into them, we find that 2015-2016 were especially interesting years for South African studies, the subjects varied and vital: Borgatti examines in a historical perspective from $16^{\text {th }}$ century to $19^{\text {th }}$ century the heritage of the African continent as this was transferred in the diaspora. ${ }^{1}$ She takes as a vivid example the work of Ade Bakare, an international fashion designer of African origin living

1. Jean M. Borgatti, "The Many Faces of Art in Global Africa," Athens Journal of Humanities $\mathcal{E}$ Arts 2, no. 4 (2015): 221-230. 
and thriving internationally." Rafapa shows how "South African Khoisan literature enriches literary discourse in the global context, using the criteria of strangeness, cross-cultural dialogue and social cohesion." ${ }^{3} \mathrm{He}$ argues that by embracing strangeness, global social cohesion grows stronger, not more fragmented. ${ }^{4}$ Finally, Van Helden in her paper uses theonome reciprocity in order to interpret the phenomenon of declining numbers in protestant mainstream churches in South Africa. ${ }^{5}$

Another conversation from another "salon" in this gathering of voices was literary, Rubik researching the portrayal of Amazons in a plethora of $17^{\text {th }}$ century English plays, ${ }^{6}$ Chakravarty investigating how Toni Morrison is using color in her novels to objectify suffering and salvation, ${ }^{7}$ and Tryniecka examining "the neoVictorian literary phenomena as an ethical, deliberate and conscious choice to retell the past anew." 8 She further researches the tendency to objectify the past in the postmodern era. ${ }^{9}$

Theatre is not only a major genre in the arts arena, but has a mix of skills and disciplines that overlap into, and enrich, a great many others. Patrick explores ways in which the intercultural performance project There's Danger in the Dance engaged with approaches to exploring difference. English performers revealed their own identities in the stage and explored ways of understanding the Filipino dances. In this way, the dancers were shown as individuals, rather than as "English" or "Filipino", working against stereotypes, and interacting in a complex manner with the notion of identity. ${ }^{10}$ Midhin and Finburgh study the dilemma of the artist in contemporary British theatre, with the contexts of art and commitment, art and politics adding complexity to one another, as well as what the artist and their art find themselves doing in (and to) society nowadays. ${ }^{11}$

2. Ibid.

3. Lesibana Rafapa, "South African Khoisan Literature in the Context of World Literary Discourse," Athens Journal of Philology 3, no. 2 (2016): 83-96.

4. Ibid.

5. Sophia Van Helden, "Theonome Reciprocity as Key for Interpreting the Phenomenon of Declining Numbers in Protestant Mainstream Churches - A South African Study," Athens Journal of Humanities \& Arts 3, no. 4 (2016): 221-238.

6. Margarete Rubik, "Women in Arms: Amazons in 17th Century English Drama," Athens Journal of Humanities E Arts 1, no. 2 (2014): 147-156.

7. Saumitra Chakravarti, "The Use of Color Imagery in the Novels of Toni Morrison," Athens Journal of Philology 2, no. 3 (2015): 163-170.

8. Aleksandra Tryniecka, "'Adaptation' or 'Appropriation': Re-narrating the Victorian Past as an Ethical Decision." Athens Journal of Humanities \& Arts 5, no. 4 (2018): 469-482.

9. Ibid.

10. Declan Patrick, "Playing with 'Others': Strategies in Intercultural Performance," Athens Journal of Humanities E Arts 2, no. 4 (2015): 231-242.

11. Majeed Mohammed Midhin, and Clare Finburgh, "The Dilemma of the Artist in Contemporary British Theatre: A Theoretical Background," Athens Journal of Humanities $\mathcal{E}$ 
Adding a layer to the complex reality of the contemporary artist, Díaz Rodríguez examines the awkward situation created from the competition between the European cultural events and the local ones on the Philippino "arts" stage. The politics of European arts funding in the Philippines adds weight further (and offkilter) to an already imbalanced landscape. ${ }^{12}$ In today's Japan, Endo explores the traveling theatre called taish $\bar{u}$-engeki (an important form of traditional theatre aims its art to a working class audience) and argues with strength that - based the duration across time it has achieved, despite its being marginalised, it has won respect (or at least acceptance) as a true Japanese form of art, at least at a subconscious level. ${ }^{13}$

In her paper on "Architecture as Frozen Music," Samsonova studies the surprising transcultural relations between Italy and Russia in the $18^{\text {th }}$ and $19^{\text {th }}$ centuries, emphasizing architecture and music. She underscores influences Italian artists had in the formation of modern culture in Russia and shows particularly how the main characteristics of Baroque and Classicism are reflected in music and architecture -- Italian master artists shaping distant culture when only the art traveled. ${ }^{14}$ Levin analyses U.S. Abstract Expressionists and how they found rich material in Greek mythology to create metaphoric meaning. He notices that for the Greek-American artists, in particular, such references grew in an almost organic way out of pride in their ancestral culture. ${ }^{15}$

One can't do Arts \& Humanities without doing at least some philosophy (or one should not). García Peña in his paper weaves almost a musical score from Plato's work, a strong theme the advantages one can gain from reading Platonic texs some post-moderns marginalize today. He argues that Platonism is "a way of understanding philosophy itself."16 Plato's work and the constant need for discussion and criticism among his students and rivals (both real and imagined in the dialogues) "will help us understand the world we live in and how to live in it." 17 Stone can hardly have found a better capstone example in a world so

Arts 2, no. 4 (2015): 243-258.

12. José Miguel Díaz Rodríguez, “The Perils of Global Cultural Promotion: (Re-) Presenting 'European Culture' in Asia through Spanish Cultural Promotion in the Philippines," Athens Journal of Humanities \& Arts 2, no. 3 (2015): 163-176.

13. Yukihide Endo, "Reconsidering the Traveling Theater of Today's Japan: An Interdisciplinary Approach to a Stigmatized Form of Japanese Theatre," Athens Journal of Humanities $\mathcal{E}$ Arts, 2, no. 3 (2015): 151-162.

14. Tatiana Samsonova, "Architecture as Frozen Music: Italy and Russia in the Context of Cultural Relations in the 18th-19th Centuries," Athens Journal of Humanities $\mathcal{E}$ Arts 4, no. 2 (2017): 123-132.

15. Gail Levin, "Greek Subjects, Greek-American Artists, and American Abstract Expressionism," Athens Journal of Humanities \& Arts 4, no. 1 (2017): 25-34.

16. Ignacio García Peña, "Platonism as a Philosophical Method," Athens Journal of Humanities \& Arts 5, no. 1 (2018): 45-60.

17. Ibid. 
affected by climate change, when he unpacks a Platonic argument that any just society will be environmentally sustainable. He then takes this a step further, to discuss the way Plato connects environmental sustainability to social justice and political stability..$^{18}$ These are (argued) morals that rise beyond the self and could breathe "lift" beneath the wings of many human efforts. O'Meara, on a related hunt, focuses particularly on Dewey's "third stage of morality," the examined, autonomous stage. The focus there is on a goal greater than the self, even when facing death. O'Meara closes the circle, taking Socrates as an example, who transformed the desires of his life so that at the "center of gravity" for his desires would be the desire to be moral. ${ }^{19}$

Serafini's paper shows how the reflexive aesthetic embedded in deconstructionist philosophy might strengthen transnational interconnections and might even be a trial basis for an authentic concept of global community. ${ }^{20}$ While Hashimoto tries to parallel the role of geometrical representations used in both the philosophical enquiries of Wittgenstein and Kuki (both try to use represented geometry in their linguistic conceptual analyses), ${ }^{21}$ it is linguistic issues that Yehudit Dror adds to the mix. He argues that different passive structures in journalistic "modern standard Arabic" do not necessarily convey different semantic content. He argues that the author's exact intention cannot be determined in all cases based on the passive structure. ${ }^{22}$

In his analyses of political speeches, Akinkurolere aims his spotlight at the meaning of context. He points out that context has necessary value as an integral part in speaker's intention and hearer's interpretation, and its influence on speech act patterns is considerable. ${ }^{23}$ Just so, from an educational perspective, Jarjoura tries to highlight the influence context on the social and pedagogical teachinglearning dynamic that Arab pre-service teachers must master. ${ }^{24}$

18. Mark Stone, "Plato, Environmental Sustainability, and Social Justice," Athens Journal of Humanities \& Arts 5, no. 1 (2018): 105-118.

19. William O'Meara, "John Dewey on Stages of Morality and Self-Realization Confronting Death." Athens Journal of Humanities \& Arts 8, no. 1 (2021): 45-62.

20. Luca Serafini, "Aesthetic Reflexivity in the Global Age," Athens Journal of Humanities \& Arts 3, no. 4 (2016): 239-250.

21. Shogo Hashimoto, "The Role of Geometrical Representations - Wittgenstein's Colour Octahedron and Kuki's Rectangular Prism of Taste." Athens Journal of Philosophy (2022) (forthcoming).

22. Yehudit Dror, "The Internal Passive and the Periphrastic Passive in Journalistic Modern Standard Arabic," Athens Journal of Philology 2, no. 2 (2015): 109-122.

23. Susan Akinkurolere, "Exploring the Significance of Context in Meaning: Speech Act Features of Performative Political Speeches of President Umaru Musa Yar'Adua," Athens Journal of Humanities \& Arts 7, no. 1 (2020): 63-84.

24. Basma Jarjoura, "Enhancing Motivation to Learn among Arab Pre-service Teachers in Arab and Mixed Colleges," Athens Journal of Education 2, no. 4 (2015): 359-382. 
Through a lens of history aimed back at the age of Roman Athens, Wick discusses how Athenian educators re-tooled the old city's schools from "classical" to "modernist" for the new clientele arriving from Republican Rome. ${ }^{25}$ While Adamidis research unearths much about the role of public services (liturgies) by litigants and their functioning in the classical Athenian courts, ${ }^{26}$ he argues that Athenians, driven by ethical as well as competitive motivation, tried to make urban justice a channel for, or main object of, the play of forensic argumentation before juries. ${ }^{27}$ In a slice from the history of health, Oberhelman archives the curious life and career of the monk Gymnasios Lavriotis, his healing recipes and therapeutic practices survive in text, and in rural Greece. By 1930, his reputation as healer had such celebrity that flocks of the sick were traveling to Thasos, where he chose to practice his craft, preferring his medical attention to the scientific doctors Greece was beginning to provide. ${ }^{28}$ In yet another "history of movement" Penava analyzes how traffic routes developed in the far south of Croatia during the 19th and 20th century. ${ }^{29}$ Finally, moving to both American history, but staying in the history of learning, Cook looks not just at amphibious assault operations in the Second World War, but at how the understanding of military decisions and how the specific plans and (very different) results of one battle can be 'learned' in ways that help and improve the next battle, or perhaps confuse it. At the heart of this point, he notes how the American victory in the 1943 Battle of Tarawa "validated" both good and flawed assumptions in the doctrine of American amphibious warfare. ${ }^{30}$

ATINER is deeply conscious of the vital element each of these papers has added to the conversation of minds "under the shadow of Lykavettos." It is a further honor, to ATINER as well as each author, that a great many of these papers coming from past conferences have qualified for publication in the Athens Journal of Humanities $\mathcal{E}$ Arts (15), and a few in the Athens Journal of History (4), the Athens Journal of Philology (3), the Athens Journal of Health and Medical Sciences (1), the Athens Journal of Education (1) and the Athens Journal of Philosophy (1).

25. David P. Wick, "Stoics and Epicureans for the 'Modern Market': How Athenian Educators Re-Tooled the Old City's 'Modernist Schools' for Republican Rome," Athens Journal of History 3, no. 4 (2017): 265-274.

26. Vasileios Adamidis, "The Relevance of Liturgies in the Courts of Classical Athens," Athens Journal of History 3, no. 2 (2017): 85-96.

27. Ibid.

28. Steven M. Oberhelman, "The Folk-Healing Recipes of the Thasian Monk Gymnasios Lavriotis," Athens Journal of Health 2, no. 3 (2015): 191-206.

29. Marija Benić Penava, "Traffic Connectivity in Croatia in the Past: The Dubrovnik Region Case," Athens Journal of History 1, no. 3 (2015): 195-204.

30. Paul J. Cook, "Peninsular Lessons for Atoll Warfare: The U.S. Marine Corps and the Development of Naval Gunfire Doctrine," Athens Journal of History 6, no. 4 (2020): 313328. 


\section{The 2022 Conference}

Not surprisingly, the vast majority of presentations of the 2022 conference were made online due to the COVID-19 pandemic which has so significantly impacted conferences, ATINER's and others, not to mention the Greek economy and society. ATINER's President, Gregory Papanikos has followed this impact in a cohesive series of papers. ${ }^{31}$ Pandemics in Athens are not new. Thucydides gives an excellent account of a pandemic which hit Athens in the first year of the Peloponnesian War in 430 BCE. ${ }^{32}$

The presentations of the 2022 conference have been organized into seven themes -- Architecture \& Urbanism, Arts, Education, Media, Literature, History, and Social Aspects, and the various abstracts are analyzed under these themes.

\section{Architecture \& Urbanism}

The "Architecture \& Urbanism" section broadly discusses the notions of space in connection with technology, art, imagery, practicality and social issues. ${ }^{33}$ The interconnection between art and architecture is a timeless question with answers that change in each age of artistry and engineering. ${ }^{34}$

In his paper titled "An Idea for Interior of Martian House", Carlo Artemi, inspired by both the successes and the aesthetic of the SpaceX programme, invites one to imagine a Martian house in its complexity, while discussing the possible difficulties and solutions connected with its construction and functionalities.

31. Gregory T. Papanikos, "The Impact of the COVID-19 Pandemic on Greek Tourism," Athens Journal of Tourism 7, no. 2 (2020): 87-100; Papanikos, "The demographics of COVID-19 in the European Union," Athens Journal of Social Sciences 7, no. 4 (2020): 279290; Papanikos, "Deaths due to COVID-19, Lockdowns, Vaccinations and Weather Temperatures: The Case of Greece," Athens Journal of Health and Medical Sciences 8, no. 3 (2021): 201-216; Papanikos, "The European Union's Recovery Plan: A Critical Evaluation," Athens Journal of Mediterranean Studies 7, no. 2 (2021): 85-102.

32. An account of this pandemic and its comparison to COVID-19 is given in: Papanikos, "Thucydides and the Synchronous Pandemic," Athens Journal of History 7, no. 1 (2021): 71-94.

33. For more information on the interesting blending of architecture with various other disciplines, please read: Clara G. Gonçalves, and Maria J. Soares, Architecture Anthology III: Inter and Transdisciplinary Relationships in Architecture II \& Crossings on Body and Architecture (Athens: Athens Institute for Education and Research, 2021); Gonçalves, and Nicholas N. Patricios, Inter and Transdisciplinary Relationships in Architecture (Athens: Athens Institute for Education and Research, 2018), and on urban theory and urbanism: Patricios, Architecture Anthology I: Architectural and Urban Theory (Athens: Athens Institute for Education and Research, 2015).

34. Rafaella Maddaluno, "Between Earth and Sky: Art and Architecture in Dialogue in the Work of Rui Chafes and Camilo Rebelo," Athens Journal of Architecture 7, no. 4 (2021): 483-498. 
What follows, in "Geography, Infrastructure and Architecture: From the Immaterial Scenes of the Arts to the Physical Space of the American City", Thomas Bisiani and Vittoria Umani discuss an artistic spatial project conducted in Dallas - a collaboration between the University Crossing Trail Public Improvement District along with the SMU University of Dallas, resulting in the promotion of an "old trail of the city" restored as an "art corridor." The project especially concentrates on the specific idea of beauty in the city landscape which, simulatenously, allows for the slowing down of the concept of time which usually dominates urban spaces.

More time machine than urban refuge, "From Urban 'Pesthole' to Urban Picturesque: White Women and Perceptions of the City at the Turn of the Twentieth Century", is Amy Johnson's argument that the critical works of Mariana Griswold van Rensselaer accompanied by Charles Mielatz's illustrations and Childe Hassam's, Alice Austen's, and Jessie Tarbox Beals's photography dramatically shifted the perception of the New York City at the turn of the nineteenth and twentieth century. As Johnson posits, these works influenced a novel perception of the city as no longer "dangerous and unhygienic" but, instead, as an "exciting world for white elites - both male and female," paving the way for the development of the notion of white supremacy, as the white women entrepreneurs would actively participate in the shaping of urban spaces while, at the same time, decreasing the visibility of immigrants and people of colour.

What follows, in Karen Large and Stephanie Sickler's paper entitled "The Influence of Music on Users' Perceptions of the Built Environment", is a discovery of the world in which it is possible to explore space without its visualization while incorporating music into the architectonic experience. Based on the study in which participants are asked to match music, fabric, and space, Large and Sickler observe that there is an "inherent meaning in and understanding of" these three components when matched together. According to Large and Sickler, incorporating music into a visual experience allows for a better understanding of a given design and greatly enhances the experience of space. Last echoing in several ways the earlier aesthetic studies, is "Music from the Rubble: Creativity as a Tool for the Promotion and Enhancement of EarthquakeHit Areas," where Mario Savini concentrates on the role of creativity as a "tool for the promotion and enhancement of earthquake-hit areas." His work discusses a sound installation involving microorganisms collected in the Central Italy from the areas hit by the earthquake in 2016. An intriguingly angled research reveals how implemented music reshapes the perception of places that have become entangled with the association of turmoil and tragedy.

\section{Arts}

The "Arts" section begins with Andrada Florian's paper, "The UnderEvaluation of National Heritage Monuments by National/Local Art Authorities", 
where the focus is on unique "heritage monuments" from the Bihor county, Romania, monuments not highlighted in any national art or heritage institutes. By contrast, as Florian maintains, the monuments which are officially appreciated are those which possess a "hidden aim" instead of "true values". Florian argues interestingly that the value of wood as a material ought to be appreciated, as wood carries a special meaning for the Romanian nation. In a parallel look at recovered organic-historical significances, "Women of the United States National Park Service: An Oral History Fine Art Film", Amanda Kline emphasizes the significance of oral histories told by women from parks across the United States, thus preserving those stories and protecting them marginalized oblivion. ${ }^{35}$ Offering women a voice carries a history beyond "dry facts" and adds the weight of art layering remembered events with personal meaning. Such narratives constitute an important testimony to the overall success of the National Parks Services (and idea) in the United States.

Michael Michael in "Interpreting Dragons: A Threefold Perspective" postulates that "dragons and dragon stories are overdetermined," arising not from either cultural, ${ }^{36}$ naturalistic or psychological causes, but from all of them together. According to the author, one should look deeper into the origins of dragons, especially reaching for the naturalistic and psychological accounts, with the latter allowing for the perception of dragons not just as cultural icons, but as Freudian echoes - parental figures and the id. Lastly, in her paper, "From Margo Channing to Margaret Elliot: The Aging Actress, Age Performance, and the Dictates of Aging in Joseph Mankiewicz's All About Eve and Stuart Hesiler's The Star", Marta Miquel-Baldellou discusses aging as a notion revealing a performative quality. The paper concentrates on the figure of the aging actress from classic films of the 1950s and 1960s who, on the one hand, might be perceived as a figure locked into roles linked to her process of decline or into subversion of those. In some cases, both seem to happen, depending on the interpretation of the performance. The aging "narrative(s)" are discussed through the comparative analysis of Joseph Mankiewicz's All About Eve and Stuart Heisler's The Star.

35. Oral histories is also an important tool of history research when there is scarcity and/or lack of original historical documents: Maysoun Ershead Shehadedh, "Five Keys of Judgment - Truth or Fiction in Autobiographical and Oral History Research: The Palestinians Oral History in Israel," Athens Journal of Mediterranean Studies (forthcoming).

36. For an investigation of dragons and women (from a ritual and cultural context), you can read: Sharon Khalifa-Guetta, "Medusa Must Die! The Virgin and the Defiled in Greco-Roman Medusa and Andromeda Myths," Athens Journal of Mediterranean Studies 7, no. 3 (2021): 201-232. 


\section{Education}

In "Give me a Place to Stand on and I Will Move the World-Contribution to the Debate on Adopting ELF Principles in Teaching EFL", Emese Boksay Pap argues that English as a Lingua Franca (ELF) in the EFL classroom should be examined by adopting the perspective of teachers, who, according to Boksay Pap, are one of the key stakeholders in the language teaching process. The author proposes that Jackson's (2008, p. 31) model of transformative learning and worldview change be adopted as a possible strategy to apply in language teachers' professional development so as to offer teachers a special "place to stand" and evaluate the issue of ELF in their own practice. Equally changeconscious is "Musical Instruments' African-Based Studies: The Application of the Afro-Brazilian knowledge to Study Non-African-Based Musical Instruments", where Adrian Estrela Pereira, Ekaterina Konopleva, Jehan Alghneimin, Nicole Kasbary and György Mészáros observe a growing interest, particularly stemming from institutional 'featuring' in Salvador city, about African-based music in Brazil. They analyse the surprising application of this trend with a study of "nonAfrican-based" musical instruments, concentrating on critical, sociological and ethnomusicological perspectives in the Brazilian context.

"Fostering Engagement and Collaborative Learning in Class through Practicing Inclusive Pedagogies", is a study in which Kelly Kirby discusses ways in which students' engagement in class discussion might be enhanced. ${ }^{37}$ The paper analyses such components as: the inclusive climate in a classroom, recognition of unconscious biases leading to a collective healing and, finally, diversity as a stronghold of classroom discussion. Last but not least, in "MultiModes of Erasure: An Analysis of the Art History and Visual Culture Curriculum", Mbali Khoza highlights the importance of multi-modal black art histories in the modern curriculum. ${ }^{38}$ As the author maintains, the inclusion of multi-modal black art histories in the narrative or fields of study at artistic institutions could invite vital conversations about black art practitioners and their approach to art, thus helping these institutions to undergo a profound change of perspective and growth.

37. For more on inclusive education, you can have a look at: Leda Kamenopoulou, "Special Issue on 'Inclusive Education': An Introduction," Athens Journal of Education 4, no. 4 (2017): 311-314.

38. For information on visual and textual representation of blackness in contemporary black expressive culture, you can read: Mbali Khoza, "Seeing Blackness through Black Expressive Culture: A Reading of Zanele Muholi's Somnyama Ngonyama - Hail the Dark Lioness," Athens Journal of Humanities \& Arts 8, no. 3 (2021): 261-286. 


\section{Media}

A "media" section approaches arts and humanities as they appear through socio-cultural, geographical, spiritual and economic lenses. In "Populism, Media and the Public Sphere in Italy", while using the method of in-depth interviews, Gennadiy Chernov discusses the phenomenon of populist parties in the South European democracies, and leads to the observation of Papanikos that "despite the differences in the practice of democracy it seems that populism cannot be avoided in all kinds of democracies." ${ }^{39}$ As Chernov notes, the issues raised by populist parties are often important to those individuals who do not identify themselves directly with the particular movement but, at the same time, feel alienated from the majority by the context of media discourse. In "Nomads, Adventure Seekers and (Non-Desperate) Housewives: Female Travel Bloggers in Cyprus", Katerina Gotsi and Margarita Ioannou offer a novel and interesting perspective on Cyrpus as one of the destinations for the $21^{\text {st }}$ century female bloggers and influencers who, in turn, share their experiences with their global audiences while using the internet. The paper explores the ways in which the female bloggers transform the experience of travel writing, as well as the ways in which Cyprus has changed itself, further influencing change in the observer, but not always with the depth one might wish. In "Media Speech on Atheism: A Study Case in Arabic Channels' Talk Shows", Lana Kazkaz \& Miriam Diez Bosch instigate a debate regarding the spread of atheism in contemporary Arab societies which can be attributed to the influence of the modern media. The paper focuses on the analyses of the concept of atheism in the Arab-Islamic world as presented and influenced by the contemporary media. Lastly, in "Exploring the Relationship Between the Performance of the Global Financial Markets and Art Market Sentiment", Peter Baur traces the complex relationship between the general financial markets and the very specific, eccentric market in fine arts, especially concentrating on echoes between art market sentiment and financial market performance. As Baur postulates, the "increasing levels of digitalization" contributed to the perception of the art market as an alternative and, possibly, beneficial investment within the financial market, protecting one from a potential market risk, but with an inevitable effect on perception of the art involved.

39. Papanikos, "Democracy and Politics: An Introduction to the Special Issue of the Athens Journal of Social Sciences," Athens Journal of Social Sciences 9, no. 2 (2022): 89-94. For more on populism in European countries, please refer to: Constantin Colonescu, "Measures of Populism in the CHES 2017 Dataset," Athens Journal of Social Sciences 9, no. 2 (2022): 95-114. 


\section{Literature}

The "Literature" section, as any literary narrative or debate qualifies, is particularly broad. In "The Lists of Sei Shōnagon; or, how an Ancient Japanese Court Lady Takes Lists on a Distinctive Turn", Allen Reichert highlights the importance and commonness of lists in this day and age. The author concentrates in particular on the on therapeutic or stress-solving elements in lists composed by the Japanese court lady Sei Shōnagon (b.965), further analyzing them in the context of Umberto Eco's works dedicated to the notion of lists as reflective, interesting and profound literary means of expression. What follows, Omar Roy' "Immanent Narrative in Franz Liszt's Vallée d'Obermann" examines Liszt's artistic work in relation to Senancour's novel Obermann and Lord Byron's Childe Harold's Pilgrimage. The aim of the paper is to explore the concept of immanent narrativity in Liszt's music through a narrative reading of Vallée d'Obermann, while especially concentrating on semiotic elements and their "interaction within a structural paradigm".

In "The Excision of Desire: Female Genital Mutilation in Alice Walker's Possessing the Secret of Joy", Khadidiatou Diallo analyses Walker's narrative presenting the pain, trauma and healing of women who, after experiencing genital mutilation, strive to regain their sense of the self, as well as their femininity, joy and the titular "secret of joy." An alternative look at triumphs in tragedy is "Utopians and Revolutionaries: A Comparative Study of P.B Shelley and Archibald Lampman", Gazala Gayas Wani emphasizes the importance of the idea of revolution for the Romantics, both in the fields of poetry and politics. While discussing the figures of P. B. Shelly, an English Romantic pet, and Archibald Lampman, a Canadian Romantic poet, (the work of neither any stranger to tragedy) Wani refers to their revolutionary Utopian ideology embracing the world in which "men could live together happily, rationally, and peacefully without any institution and class distinction."

\section{History}

The "History" section hosts an engaging paper by David Philip Wick entitled "The Figurines and the Fear of Philip - A Glimpse or Two at the Key Crisis Moments when Greeks Invited Rome into the Aegean, and the Ancient Play Between Urban Identity Politics and Pop Culture Art". ${ }^{40}$ The developing paper, intended for an evolved presentation at the next history conference, is dedicated

40. Wick, "The Figurines and the Fear of Philip - A Glimpse or Two at the Key Crisis Moments when Greeks Invited Rome into the Aegean, and the Ancient Play Between Urban Identity Politics and Pop Culture Art," to be presented in the $20^{\text {th }}$ Annual International Conference on History \& Archaeology: From Ancient to Modern, 30-31 May \& 1-2 June 2022. Athens, Greece. 
to the exploration of the selected key moments of crisis (between 205 and 151 of the old era) that "punctuated the Greek invitation of Rome into the Aegean", thus changing the cultural eco-systems of ancient cities like Athens, and which led Athens to attempt capture of new artistic industries and styles in its region that might speak 'Greek' to its new, outlander, incoming wave of culture.

\section{Social Aspects}

In the "Non-Objective Criterion of 'Defamation by Publicly Alleging Facts' in Korea's Current Criminal Law", Jayoung Che discusses the complex notion of defamation as the unique form of the crime which is "prosecuted, tried [and] punished" in Korea. Persecuting an individual for defamation often stems from and results in "subjective" and "arbitrary" judgments, as the paper argues that there are "loopholes in the law" (including the clue of "public interest") that allow for the interference of subjective judgments. In a somewhat similar study of the concrete entangled in the personal "From Design Thinking to Designing Inclusive Collaborations", Franz Christian Schneider observes that only through recognition and integration of "diverse cultural content, values and knowledge" we are able to offer desired answers to the social and economic needs, as well as the issues of climate change and immigration. The process of integration is not simple, nor one-dimensional (as true believers often wish it to be), but an ongoing dynamic and complicated process of mutual adaptation and pluralism. ${ }^{41}$ As the author points out, our societies and economic structures undergo a constant and profound change, hence isolation of one system is not possible and only integrative methods of work will bring the desired effect, that is - inclusive living systems based on teamwork and collaboration.

"Social Responsibility Through Arts" is a broad-ranging discussion in which Radmila Janicic follows various arts through practical and theoretical aspects of social responsibility they attempt to express. The paper ranges from case studies embracing painting, photography, to literature and history. As the study suggests, social responsibility expressed through artistic outlets simultaneously allows for the discussion of "thoughts, ideas [and] values, that otherwise could be unnoticed." This might almost be the perfect introduction to "Why We Tell the Story: The Modern Need for Aristotelian Tragedy to Facilitate Civil Discourse in a Divided Society", where Michael Mazur invites the question of the "honest civil discourse" on which every society greatly depends. While introducing the example of Aristotle who created a list of the "elements of tragedy", Mazur debates the notion of contemporary tragic stories which could "challenge and inspire (...) global citizens." Even when detached from the classic literary traditions, such modern stories, including the musical Once on this Island, still

41. Sara Arnon, and Shmuel Shamai, "Integrating Immigrant and Absorbing Groups into a Joint Community," Athens Journal of Social Sciences 3, no. 4 (2016): 321-336. 
fulfill Aristotelian requirements for the genre of tragedy, while innovatively offering plots and meanings with which the global citizens might easily identify.

\section{Conclusions}

Just this selected survey of papers on Humanities and Arts offers a lively example of the very broad range of thematics covered by any of the ATINER Arts \& Humanities conferences. From the playful relationship between art and architecture or the deep but easily-missed role that music plays in the perception of the space and our "built" environment, to how art education can be if we see the possibilities with creative eyes. Add in the value of fluid, equal and open inclusive threads of education, to the transformative curricula to include multimodal histories and expression from overlooked cultures or cultures we have always looked at in stereotyped ways.

It is heart-warming to see included a significant role for often-belittled forms of cultural expression and evidence - the vitality of oral histories, the women's experiences of a National Parks in the United States or a culture stressed by conflict but eager to be liked at that on Cyprus. And a flock of dragons. Monotonal is something ATINER, in our experience, has never been.

We heard aspects of media, discussable and purely emotive, in court from ancient Greece to modern Korea. Bloggers and "influencers" can today be both well-paid professions and the wielders heavy and not-always-ethical cultural power, but their equivalents flourished as far back as the classical world.

The literary angles were as wide-ranging as they have usually become critiqueing multilayered socio-cultural issues and perspectives, with narrative, biographical, rhetorical, and fictional, analyses and comparison, narratives included and narratives examined, not to mention the embroidery of composed lists and idealistic poets. And the dark side of the social was there as well as the creative, reminding us that in today's democracies, where populism, cultural fundamentalism or authoritarianism exist, there are by necessity contemporary tragedies generated, stories, song and images that challenge and inspire global citizens, and, where they are allowed by civility, can provoke honest civil discourse.

This survey is as much an invitation as an enumeration, or one of those "therapeutic lists" mentioned a few paragraphs ago. Any reader who has made it this far may find a great deal of ... a great variety of ... nodes and perspectives of wisdom awaiting in the many angled investigations this slice of ATINER's invited scholarship can show. But nodes of wisdom require thinking and conversation, thesis and critique, exactly the flow of give-and-take ATINER hoped, a few decades ago, to insert into the thunder of soliloquy that is too often an academic conference in the $21^{\text {st }}$ century. We hope you enjoy reading in these 
pages; we hope even more you will be inspired to research in your own field and offer that for consideration to present in the small, lively discussions that are our trademark when COVID-19 again allows then to happen in Athens, and online until that is possible.

\section{Bibliography}

Adamidis, Vasileios. "The Relevance of Liturgies in the Courts of Classical Athens." Athens Journal of History 3, no. 2 (2017): 85-96.

Akinkurolere, Susan. "Exploring the Significance of Context in Meaning: Speech Act Features of Performative Political Speeches of President Umaru Musa Yar'Adua." Athens Journal of Humanities $\mathcal{E}$ Arts 7, no. 1 (2020): 63-84.

Arnon, Sara, and Shmuel Shamai. "Integrating Immigrant and Absorbing Groups into a Joint Community." Athens Journal of Social Sciences 3, no. 4 (2016): 321-336.

Borgatti, Jean M. "The Many Faces of Art in Global Africa." Athens Journal of Humanities \& Arts 2, no. 4 (2015): 221-230.

Chakravarti, Saumitra. "The Use of Color Imagery in the Novels of Toni Morrison." Athens Journal of Philology 2, no. 3 (2015): 163-170.

Colonescu, Constantin. "Measures of Populism in the CHES 2017 Dataset." Athens Journal of Social Sciences 9, no. 2 (2022): 95-114.

Cook, Paul J. "Peninsular Lessons for Atoll Warfare: The U.S. Marine Corps and the Development of Naval Gunfire Doctrine." Athens Journal of History 6, no. 4 (2020): 313328.

Díaz Rodríguez, José Miguel. “The Perils of Global Cultural Promotion: (Re-) Presenting 'European Culture' in Asia through Spanish Cultural Promotion in the Philippines." Athens Journal of Humanities \& Arts 2, no. 3 (2015): 163-176.

Dror, Yehudit. "The Internal Passive and the Periphrastic Passive in Journalistic Modern Standard Arabic." Athens Journal of Philology 2, no. 2 (2015): 109-122.

Endo, Yukihide. "Reconsidering the Traveling Theater of Today's Japan: An Interdisciplinary Approach to a Stigmatized Form of Japanese Theatre." Athens Journal of Humanities \& Arts, 2, no. 3 (2015): 151-162.

García Peña, Ignacio. "Platonism as a Philosophical Method." Athens Journal of Humanities $\mathcal{E}$ Arts 5, no. 1 (2018): 45-60.

Gonçalves, Clara G., and Maria J. Soares. Architecture Anthology III: Inter and Transdisciplinary Relationships in Architecture II E Crossings on Body and Architecture. Athens: Athens Institute for Education and Research (ATINER), 2021.

Gonçalves, Clara G., and Nicholas N. Patricios. Inter and Transdisciplinary Relationships in Architecture. Athens: Athens Institute for Education and Research (ATINER), 2018.

Hashimoto, Shogo. "The Role of Geometrical Representations - Wittgenstein's Colour Octahedron and Kuki's Rectangular Prism of Taste." Athens Journal of Philosophy 1, no. 1 (2022): 9-24.

Jarjoura, Basma. "Enhancing Motivation to Learn among Arab Pre-service Teachers in Arab and Mixed Colleges." Athens Journal of Education 2, no. 4 (2015): 359-382.

Kamenopoulou, Leda. "Special Issue on 'Inclusive Education': An Introduction." Athens Journal of Education 4, no. 4 (2017): 311-314. 
Khalifa-Guetta, Sharon. "Medusa Must Die! The Virgin and the Defiled in Greco-Roman Medusa and Andromeda Myths." Athens Journal of Mediterranean Studies 7, no. 3 (2021): 201-232.

Khoza, Mbali. "Seeing Blackness through Black Expressive Culture: A Reading of Zanele Muholi's Somnyama Ngonyama - Hail the Dark Lioness." Athens Journal of Humanities \& Arts 8, no. 3 (2021): 261-286.

Levin, Gail. "Greek Subjects, Greek-American Artists, and American Abstract Expressionism." Athens Journal of Humanities \& Arts 4, no. 1 (2017): 25-34.

Maddaluno, Rafaella. "Between Earth and Sky: Art and Architecture in Dialogue in the Work of Rui Chafes and Camilo Rebelo," Athens Journal of Architecture 7, no. 4 (2021): 483-498.

Midhin, Majeed Mohammed, and Clare Finburgh. "The Dilemma of the Artist in Contemporary British Theatre: A Theoretical Background." Athens Journal of Humanities \& Arts 2, no. 4 (2015): 243-258.

O'Meara, William. "John Dewey on Stages of Morality and Self-Realization Confronting Death." Athens Journal of Humanities \& Arts 8, no. 1 (2021): 45-62.

Oberhelman, Steven M. "The Folk-Healing Recipes of the Thasian Monk Gymnasios Lavriotis." Athens Journal of Health 2, no. 3 (2015): 191-206.

Papanikos, Gregory T. Humanities and Arts in a Global World: Abstract Proceedings of the 1st Annual International Conference. Athens: Athens Institute for Education and Research (ATINER), 2014.

. Humanities and Arts in a Global World: Abstract Proceedings of the 2nd Annual International Conference. Athens: Athens Institute for Education and Research (ATINER), 2015.

. Humanities and Arts in a Global World: Abstract Proceedings of the 3rd Annual International Conference. Athens: Athens Institute for Education and Research (ATINER), 2016.

. Humanities and Arts in a Global World: Abstract Proceedings of the 4th Annual International Conference. Athens: Athens Institute for Education and Research (ATINER), 2017.

. Humanities and Arts in a Global World: Abstract Proceedings of the 5th Annual International Conference. Athens: Athens Institute for Education and Research (ATINER), 2018.

. Humanities and Arts in a Global World: Abstract Proceedings of the 6th Annual International Conference. Athens: Athens Institute for Education and Research (ATINER), 2019.

. Humanities and Arts in a Global World: Abstract Proceedings of the 7th Annual International Conference. Athens: Athens Institute for Education and Research (ATINER), 2020.

. "The Impact of the COVID-19 Pandemic on Greek Tourism." Athens Journal of Tourism 7, no. 2 (2020): 87-100.

. "The demographics of COVID-19 in the European Union." Athens Journal of Social Sciences 7, no. 4 (2020): 279-290.

. Humanities and Arts in a Global World. Abstract Proceedings of the 8th Annual International Conference. Athens: Athens Institute for Education and Research (ATINER), 2021. 
. "Deaths due to COVID-19, Lockdowns, Vaccinations and Weather Temperatures: The Case of Greece." Athens Journal of Health and Medical Sciences 8, no. 3 (2021): 201216.

. "The European Union's Recovery Plan: A Critical Evaluation." Athens Journal of Mediterranean Studies 7, no. 2 (2021): 85-102.

. "Thucydides and the Synchronous Pandemic." Athens Journal of History 7, no. 1 (2021): 71-94.

. "Democracy and Politics: An Introduction to the Special Issue of the Athens Journal of Social Sciences." Athens Journal of Social Sciences 9, no. 2 (2022): 89-94.

Patricios, Nicholas N. Architecture Anthology I: Architectural and Urban Theory. Athens: Athens Institute for Education and Research (ATINER), 2015.

Patrick, Declan. "Playing with 'Others': Strategies in Intercultural Performance." Athens Journal of Humanities \& Arts 2, no. 4 (2015): 231-242.

Penava, Marija Benić. "Traffic Connectivity in Croatia in the Past: The Dubrovnik Region Case." Athens Journal of History 1, no. 3 (2015): 195-204.

Rafapa, Lesibana. "South African Khoisan Literature in the Context of World Literary Discourse." Athens Journal of Philology 3, no. 2 (2016): 83-96

Rubik, Margarete. "Women in Arms: Amazons in 17th Century English Drama." Athens Journal of Humanities \& Arts 1, no. 2 (2014): 147-156.

Samsonova, Tatiana. "Architecture as Frozen Music: Italy and Russia in the Context of Cultural Relations in the 18th-19th Centuries." Athens Journal of Humanities $\mathcal{E}$ Arts 4, no. 2 (2017): 123-132.

Serafini, Luca. "Aesthetic Reflexivity in the Global Age." Athens Journal of Humanities \& Arts 3, no. 4 (2016): 239-250.

Shehadedh, Maysoun Ershead. "Five Keys of Judgment - Truth or Fiction in Autobiographical and Oral History Research: The Palestinians Oral History in Israel." Athens Journal of Mediterranean Studies (forthcoming).

Stone, Mark. "Plato, Environmental Sustainability, and Social Justice." Athens Journal of Humanities \& Arts 5, no. 1 (2018): 105-118.

Tryniecka, Aleksandra. "'Adaptation' or 'Appropriation': Re-narrating the Victorian Past as an Ethical Decision." Athens Journal of Humanities \& Arts 5, no. 4 (2018): 469-482.

Van Helden, Sophia. "Theonome Reciprocity as Key for Interpreting the Phenomenon of Declining Numbers in Protestant Mainstream Churches - A South African Study." Athens Journal of Humanities \& Arts 3, no. 4 (2016): 221-238.

Wick, David P. "Stoics and Epicureans for the 'Modern Market': How Athenian Educators Re-Tooled the Old City's 'Modernist Schools' for Republican Rome." Athens Journal of History 3, no. 4 (2017): 265-274.

. "The Figurines and the Fear of Philip - A Glimpse or Two at the Key Crisis Moments when Greeks Invited Rome into the Aegean, and the Ancient Play Between Urban Identity Politics and Pop Culture Art." To be presented in the 20 $2{ }^{\text {th }}$ Annual International Conference on History \& Archaeology: From Ancient to Modern, 30-31 May \& 1-2 June 2022. Athens, Greece. 
